\title{
When Emotional Problems Explode
}

When asking dermatologists what kind of disorders they consider most significant under a psychological point of view the answer will mostly be: Factitious disorders. The present issue of Dermatology + Psychosomatics addresses these disorders in a spectrum of articles, case presentations and the education part as well as in a description of the German self-help group 'Rote Linien' ('red lines') on self-inflicted lesions. When emotional problems build up, they may find an outlet in the skin. In most of the cases, factitious disorders are produced unconsciously and remain secret. However, more and more people cut their skin with knives, burn themselves with cigarettes or even drink acids when they cannot handle their emotions anymore. The dermatological lesions thus caused vary considerably depending on the automutilative method used. 'The more I examined self-mutilation, the more puzzling it seemed' writes Favazza [1996] in his book on self-mutilation in which cultural and psychiatric theories and explanations are gathered. If one takes into account the high number of undetected cases, the prevalence of factitious disorders seems close to that of eating disorders. Just have a close look at this issue's 'Education' where you will find the German Guideline on Factitious Disorder.

Sylvie Consoli [1995] has described the history of 'dermatitis artefacta'. This term was coined in 1908 by Bourget. All the same, Anna Zalewska [2004] in this issue's report quotes descriptions of dermatitis artefacta reaching as far back as 5th century B.C. Patients with factitious disorders seen by dermatologists or seen by psychiatrists have very different personality structures although most of them have borderline personality disorders. The DSM-IV clearly distinguishes between 'artificial disorders' (or factitious disorders; dermatitis artefacta) and simulation. With regard to secrecy as an essential characteristic to the nosological implications, we further distinguish so-called 'para-artificial' disorders such as neurotic excoriations, morsicatio buccarum or onychophagia. These represent more conscious problems and should be discussed with the patients as behavior or sometimes obsessive-compulsive disorders [Gieler, 1994]. Konzag et al. [2004] point out that psychodymanics allow differentiation of two subgroups: a subgroup of patients who have grown up in an existentially threatening milieu that violated their physical integrity, and a subgroup who has been subjected at the emotional level to experiences of withholding and aggression. They established a three-phase treatment concept which made long-lasting improvements of symptoms possible. So the authors have demonstrated possible treatment strategies, although often psychotherapy is not possible with these patients because of their inability to communicate adequately. Often self-therapy creates psychological areas of resistance that are best left intact by the psychotherapist. Fliege et al. [2004] demonstrate that it is possible to make a scientific research study with selfharming patients and point to the differences of overt or covert self-harm. Over the last years, we have also benefited from the experiences of psychotherapy with post-traumatic or borderline personality disorders as well from the psychodynamic [Clarkin et al., 1993] or behavioral points of view [Linehan, 1993]. Treatment of patients with factitious disorders may be very similar to that of patients with post-traumatic disorders because many of those have experienced severe traumata and violence.

Two casuistic contributions presented in this issue deal with special cases of self-inflicted practices [Garcia-Bustinduy et al., 2004; Capella, 2004]. Besides, you will find some interesting aspects on psychosomatic complaints [Seikowski and Reinwardt, 2004] and a psychoimmunological study on psoriasis and pruritus from the Polish research team of Wiśnicka et al. [2004].

I would like to invite you to reading about the manifold aspects of factitious disorders in the present issue of DERMATOLOGY + PSYCHOSOMATICS and I hope you will enjoy it without becoming auto-aggressive.

Uwe Gieler, Giessen

\begin{tabular}{ll}
\hline KARGER & ( ) 2004 S. Karger GmbH, Freiburg \\
Fax +4976145207 14 & Accessible online at: \\
$\begin{array}{l}\text { E-mail Information@Karger.de } \\
\text { www.karger.com }\end{array}$ & www.karger.com/dps
\end{tabular}

Prof. Dr. Uwe Gieler

Clinic for Psychosomatics and Psychotherapy

Justus-Liebig-Universität Gießen

Ludwigstr. 76, D-35393 Gießen

Tel. +49 64199 45650, Fax 9945659

E-mail uwe.gieler@psycho.med.uni-giessen.de 


\section{References}

Capella GL: Plantar petechiae as a clue of sadomasochistic practices - an unexpected form of 'dermatitis erotica'. Dermatol Psychosom 2004;4:88-92.

Clarkin JF, Hull JW, Hurt SW: Factor structure of borderline personality disorder criteria. J Pers Disord 1993;7:137-143.

Consoli SG: Dermatitis artefacta: A general review. Eur J Dermatol 1995;5:5-11.

Favazza AR: Bodies under Siege - Self mutilation and Body Modification in Culture and Psychiatry. Baltimore, MD, Johns Hopkins University Press, 1996.

Fliege H, Kocalevent RD, Rose M, Becker J, Walter M, Klapp DF: Patients with overt or covert selfharm: Differences in optimism and self-efficacy. Dermatol Psychosom 2004;4:54-60.
García-Bustínduy M, Guimerá F, Sánchez-González R, Rodríguez F, Fagundo E, Sáez M, Álvarez-Peñate N, Henry M, Noda-Cabrera A, García-Montelongo R: Factitious disorder: A patient with a recurrent tumour. Dermatol Psychosom 2004;4:85-87.

Gieler U: Factitious disorders in the field of dermatology: Psychother Psychosom 1994;62:48-55.

Konzag TA, Baumgärtner C, Fikentscher E, Taube KM: Personality typology and reatment phases in patients with self-inflicted dermatological injuries. Dermatol Psychosom 2004;4:61-64.

Linehan MM: Cognitive-Behavioral Treatment of Borderline Personality Disorder. New York, Guilford, 1993.
Seikowski K, Reinwardt U: Frequency and clinical relevance of psychosomatic complaints in skin patients. Dermatol Psychosom 2004;4:65-72.

Wiśnicka B, Szepietowski JC, Reich A, Orda A: Histamine, substance $\mathrm{P}$ and calcytonin gene-related peptide plasma concentration and pruritus in patients suffering from psoriasis. Dermatol Psychosom 2004;4:73-78

Zalewska A: Clinical picture of self-inflicted skin lesions. Dermatol Psychosom 2004;4:79-84. 